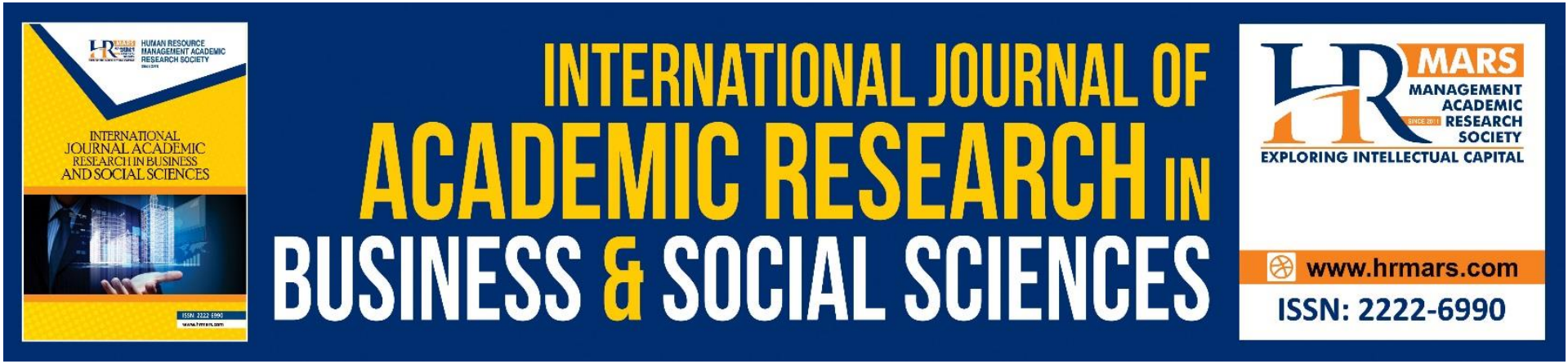

\title{
Crisis Communication Relief Management and Preparedness: Covid-19 Disease Outbreak for Indigenous Peoples in Malaysia
}

Sara Chinnasamy, Mohd Roslan Rosnon \& Sarjit. S. Gill

To Link this Article: http://dx.doi.org/10.6007/IJARBSS/v11-i11/11770

DOI:10.6007/IJARBSS/v11-i11/11770

Received: 12 September 2021, Revised: 15 October 2021, Accepted: 30 October 2021

Published Online: 18 November 2021

In-Text Citation: (Chinnasamy et al., 2021)

To Cite this Article: Chinnasamy, S., Rosnon, M. R., \& Gill, S. S. (2021). Crisis Communication Relief Management and Preparedness: Covid-19 Disease Outbreak for Indigenous Peoples in Malaysia. International Journal of Academic Research in Business and Social Sciences, 11(11), 2499-2511.

Copyright: (c) 2021 The Author(s)

Published by Human Resource Management Academic Research Society (www.hrmars.com)

This article is published under the Creative Commons Attribution (CC BY 4.0) license. Anyone may reproduce, distribute, translate and create derivative works of this article (for both commercial and non0-commercial purposes), subject to full attribution to the original publication and authors. The full terms of this license may be seen at: http://creativecommons.org/licences/by/4.0/legalcode

Vol. 11, No. 11, 2021, Pg. $2499-2511$

Full Terms \& Conditions of access and use can be found at http://hrmars.com/index.php/pages/detail/publication-ethics 


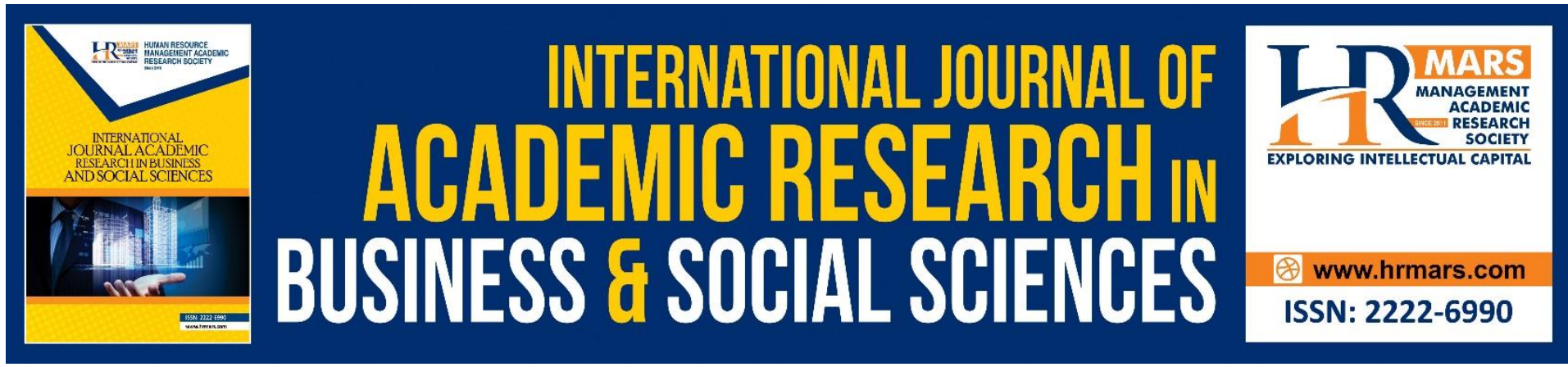

\title{
Crisis Communication Relief Management and Preparedness: Covid-19 Disease Outbreak for Indigenous Peoples in Malaysia
}

\author{
Sara Chinnasamy \\ Faculty of Communication \& Media Studies, Universiti Teknologi MARA (UiTM) \\ 40450 Shah Alam, Selangor \\ Mohd Roslan Rosnon \& Sarjit. S. Gill \\ Department of Social and Development Sciences, Faculty of Human Ecology, \\ Universiti Putra Malaysia, 43400 Serdang, Selangor \\ Email: roslan_rosnon@upm.edu.my
}

\begin{abstract}
The COVID-19 pandemic has created a global crisis that has impacted all aspects of humanity. As of August 16, 2021, Malaysia has seen significant increases in active cases. However, the condition of indigenous peoples remains a question mark and it is unknown what steps have been taken to address this group. Do they understand the prevalence of the COVID-19 outbreak and what strategies are being taken to prevent this outbreak among the Indigenous people? Although there is crisis or disaster management related stakeholders, yet the Crisis Communication Relief Management and Preparedness is vital especially for the Indigenous people because they are important group of mainstream society. Indigenous peoples are among the most vulnerable and at risk of COVID 19 pandemic. The discussion is augmented by Foucault's notion of power and governmentality, aspects related to decision-making about Crisis Communication Relief Management and Preparedness. The analysis of Foucault's Power, knowledge and governmentality gives a clear understanding on how the government in regulating and shaping the Crisis Communication Relief Management and Preparedness to the specific groups such as the Indigenous people.
\end{abstract}

Keywords: Orang Asli, COVID-19, Crisis Communication Relief Management, Preparedness, Governmentality

\section{Introduction}

The spread of infectious diseases can pose significant threats and control over unforeseen events. These disasters can threaten and challenge the ability to cope with difficulties not only by the community but also by the authorities. Moreover, proper and well-managed approaches should be used to help the indigenous people in Malaysia. The Aboriginal community is a high-risk group and needs early steps to curb the spread of this infectious disease. 
We were previously shocked by an epidemic like SARS but the dissemination of information was not as great and as speed today. Today's COVID-19 invaders are not only a challenge to overcome the spread of the epidemic but also a challenge in controlling information in the media of the time so that there is no news and false information. This is due to increased use of social media. In Malaysia, there are critical factors in determining the policy requirements for crisis communication management. The Center for Crisis and Preparedness under the Ministry of Health Malaysia currently needs to be merged with a number of key agencies. These agencies can no longer operate on their own but must be well organised and coordinated. Risk management for infectious diseases needs to change and move towards a comprehensive approach in response to new scientific approaches, discoveries in research in the fields of natural sciences, arts and social sciences. Modeling best practices in managing crisis communications through an integrated approach is essential to curb the spread of infectious diseases in the context of indigenous peoples in Malaysia.

An outbreak of infectious diseases has occurred among Aboriginal people in the last 2020. A total of 15 deaths have been recorded in this tragedy (Ministry of Health Malaysia, 2019). The crisis management systems in the pre and post-infectious outbreaks for the Kuala Koh case are not well coordinated as there is no SOP (Standard of Procedure) to handle the Kuala Koh case. Eventually, speculation spread about the outbreak in local newspapers and social media. As such, it is time for setting up a Crisis Communication Relief Management and Preparedness for special needs to be created.

In other countries such as Canada, Australia, and New Zealand, for instance have special teams to assist and prevent the spread of outbreaks for indigenous peoples in their countries (Smith-Morris \& DeLuca, 2020). This is in line with the United Nations Declaration of Rights on Indigenous People (UNDRIP) (UNDRIP, 2007). The Committee was established to provide special policies to assist indigenous peoples and to tackle discrimination, racial issues and to provide better access to health and well-being (National Aboriginal Community Controlled Health Organization, 2020). For an example, the Australian Government established an Aboriginal people and Torres Strait Islander Advisory Group for COVID-19 to provide advice on health issues related to indigenous peoples (National Indigenous Australia Agency, 2020). Therefore, it is imperative to establish specific guidelines and mechanisms to curb the spread of this epidemic in developing country like Malaysia especially among the indigenous peoples. Therefore, the development of Crisis Communication Relief Management and Preparedness is seen as important in the current and post COVID 19 crisis management of infectious diseases among Aboriginal people.

There is a crisis management in Malaysia, in terms of information circulation, relief management and preparedness for the Orang Asli population. This community is considered very important among Malaysian population because they are a distinct group of mainstream society. Indigenous peoples are among the most vulnerable and at risk for this pandemic for several reasons. First, their geographical location and community characteristics of Indigenous communities are remote and isolated. Economic conditions and limited food resources and facilities services had transformed this group to be vulnerable (Razali, Rosnon \& Sarjit, 2021; Rosnon et al., 2019; Sarjit et al., 2010). Secondly, biological factor of indigenous peoples. Most indigenous peoples are elders. Lack of nutrition and disease resistance make them at higher risk of developing COVID-19 (Rosnon, 2020). Third is the role of Indigenous 
peoples in their families and communities. Indigenous peoples are vulnerable communities, often living in extended families that continuance multiple generations (Nicholas, 2002). Therefore, isolation in the home does not occur and is vulnerable to this outbreak. Fourth is the culture factor. The whole indigenous community is very close and culturally attached. Older people often play a leading role in their community gatherings, for instance cultural dances, healing ceremonies, or cultural affairs such as death and marriage conduct. Limiting access to older people and community members in cultural management is difficult to implement in the global pandemic (Nicholas, 2005). As such, Crisis Communication Relief Management and Preparedness during the pre- and post-infectious outbreaks for indigenous peoples in Malaysia are crucial to encounter the spread of the COVID-19 outbreak.

\section{Pandemic COVID-19 And Indigenous People}

The COVID-19 pandemic, also known as the Coronavirus 2019 pandemic, is a global epidemic and is the result of Coronavirus 2 (SARS-CoV-2) respiratory syndrome. The outbreak was first detected in mid-December 2019 in the city of Wuhan, Hubei China, and was declared a pandemic by the World Health Organization (WHO) on March 11, 2020 (World Health Organization, 2020b). As of August 16, 2021, more than 208,248,758 COVID-19 cases have been reported in at least 180 countries and territories, resulting in more than 4,379,303 deaths and 186,713,793 recoveries (World Health Organization, 2021a). The United States recorded the highest casualties with 637,561 deaths, followed by Brazil $(569,218)$, India $(431,900)$, Mexico $(248,380)$, Peru $(197,393)$, Russia $(171,305)$ and United Kingdom $(130,979)$. China, however, remains at 4,636 deaths (World Health Organization, 2021a). While in Malaysia it was reported that as of August 16, 2021 there were 1,424,639 cases of COVID-19, 12,784 deaths and 1,162,578 recoveries (World Health Organization, 2021a). Over 3.9 billion people - half of the world's population - are being asked or ordered by authorities to stay indoors in over 90 countries and territories, according to AFP database information (Worldometers, 2021).

In Malaysia, a first case involving 3 years old child Orang Asli has been reported by a local newspaper in 2020. There are two Aboriginal villages under the Restricted Movement Control Order (PKPD) in Sungai Lui, namely the Paya Lebar Orang Asli Village and the Gabai River Aboriginal Village (Rosnon, 2020). As of August 12, 2021, a total of 784 Orang Asli residents in Mukim Bidor, who are under the enhanced movement control order, have tested positive for Covid-19, and eight have succumbed to the virus (The Star, 2021). This phenomenon has caused the indigenous people to fear and escaped to the jungle as reported by local media. Indigenous peoples are minorities, both geographically, socially, psychologically and economically, although some of these communities have been incorporated into the mainstream of Malaysian society (Rosnon, 2016; Rosnon \& Abu Talib, 2019; Rosnon, Abu Talib \& Abdul Rahman, 2019; Rosnon \& Sara, 2015). They consist of three races, namely Senoi, Proto-Malays and Negritos (Orang Asli Development Department, 2016). Senoi is the largest, with a total 97.856 people (54.9 percent), followed by the Proto-Malays with a total 75.332 people (42.3 percent) and Negrito with a total of 5,009 persons (2.8 per cent) (Department of Orang Asli, 2016, pp. 23 -24). The 2010 census shows that the number of Aboriginal people is 178,197 in Peninsular Malaysia (Aboriginal Development Department, 2016, p. 24). In terms of residential distribution, it was found that 6 Aboriginal settlements were located in urban areas, 539 were in the suburbs and 308 were in the interior (Aboriginal Development Department, 2016, p. 30). 
Crisis Communication Relief Management and Preparedness for Special Aborigines is seen as crucial to the care of the Aboriginal community when the abduction takes place. Infectious disease management, COVID-19 is a shared responsibility of various stakeholders such as government agencies, NGOs, the private sector, the media and the entire community. Coordination across multiple levels is very much needed and full cooperation is the backbone of the coordination network to be strengthened. In addition, the enhancement of performance capabilities through training and co-operation between agencies such as the National Security Council and several agencies including those involved in the care of Aboriginal people is very important in improving the management of infectious diseases. Good coordination will create integrated action.

In addition, the existence of active non-governmental organizations (NGOs) in Malaysia should be included in the management of infectious diseases. In the case of COVID-19, most NGOs carried out separate operations without the full involvement or coordination of the National Security Council and other agencies or ministries, including the indigenous people. Proposed use of NGOs, such as the Malaysian Red Crescent Society at every level of management can also assist in the operations of disaster relief and disaster management. This coordination can exploit existing resources and assets and can launch more operations. Non-governmental organizations (NGOs) and private bodies and residents should also be involved in the policy process, evaluating and creating agendas for the Infectious Disease Management and Management Committee. Each country has its own policies and policies to deal with outbreaks. Malaysia has a technique that can be used as a location that can provide data and help pre, during and after the tragedy, Malaysia needs to improve the pre- and postCOVID-19 communication framework to avoid the negative effects of the COVID-19 outbreak management disaster.

Compared to countries such as Australia, many have been featured in local media for information and advice on the control of Coronavirus (COVID-19) for Aboriginal People and Torres Straits Islander communities (Department of Health Australia, 2020). Aboriginal People and Torres Straits Islanders and communities living in remote areas are categorized as high risk for COVID-19. This is because these groups have other chronic health problems, difficulties in accessing health care and free community movement. Also in Australia, those living in remote areas are a priority of the Australian Government until the COVID-19 National Emergency Action Plan has been designed specifically for Aboriginal People and Torres Straits Islander communities to safeguard the safety and spread of the outbreak (National Indigenous Australia Agency, 2020). This is because Aboriginal People and Torres Straits Islanders and communities living in remote areas are at greater risk of being infected with the COVID-19 outbreak. Most Aboriginal People and Torres Straits Islander Australians are trapped in their area and Australian health workers are preparing to block the spread of COVID-19 (National Aboriginal Community Controlled Health Organization, 2020). To date, the service, known as Purple House, has been used to run dialysis centers in 18 remote community areas across the vast central Australian region especially in the desert areas (Department of Health Australia, 2020).

\section{Methodology}

This concept article adopts by Foucault's notion of power and governmentality, aspects related to decision-making about Crisis Communication Relief Management and 
Preparedness. The analysis of Foucault's Power, knowledge and governmentality gives a clear understanding on how the government in regulating and shaping the Crisis Communication Relief Management and Preparedness to the specific groups such as the Indigenous people. Therefore, drawing on Foucaul's work, the COVID-19 Communication Relief Management and Preparedness should be considered during this pandemic. Otherwise, it will be a long due struggle for the human conducts of govermentality towards the management of indigenous people in the country. The proposed model in this paper can be used as a guide for communication crisis model among the indigenous community and the stakeholders.

\section{Crisis Communication Relief Management and Preparedness: Connecting Power and Governmentality to Orang Asli}

The idea of introducing crisis communication relief management and preparedness to Orang Asli in Malaysia can be critically examined from the perspective of "governmentality". Governmentality gives a new understanding of power relations; different from that found in traditional liberal and Marxist theories of power (Mills, 2003). This theoretical perspective would help to understand the circumstance that involved in the policy making in Malaysia.

A French philosopher; Foucault $(1991$, p. 87) created a term called "governmentality" in which it explained the governance of populations in the history of modern Europe. This concept does not only include the procedures and techniques on the political or administrative aspects but also for both individuals and the community at every social level. As described by Foucault, the concept is applicable to three types of government which are "government of the self", "government of others" and "government of the state" (Dean, 1999, p. 2). His work on governmentality linked with the concept of "government rationality" and/or "the art of government" (Foucault, 1991, p. 90). His argument emphasis more to the execution and actions or practices of a government such as the aspects of governing, who is being governed and who can govern. Foucault (cited in Gordon, 1991, p. 2) alternatively describes government's function as "the conduct of conduct", which explains the term "problematic nature of government" (Smart, 2002, p. xiv).

The term of governmentality can be defined in two different perspectives. According to Larner and Walters (2004), firstly, as a state's execution of power, which is "not for territorial defence or to aggrandizement of the sovereign but optimization of the health and welfare of the population" (p.2). Secondly, complex relationship between the people and government, which is more to the method of discovery. This include how particular mechanisms, such as representation or statement, knowledge and expertise have been involved in the process of governing with regards to what and who is to be governed.

Scholars who extended Foucault's work simplied that his work deals with the matter of how the conduct of self and others is formed and regulated by a series of practices in various forms. Among the existing scholars, Dean (1999, p. 11) was well-known in expanding Foucault's concept of governmentality in a more comprehensive and clearer stand. Dean brought a different perspective of government's function, which does not only mean to give orders to the people, but also involves the attempt to plan and command the human conduct.

Government is any more or less calculated and rational activity, undertaken by a multiplicity of authorities and agencies, employing a 
variety of techniques and forms of knowledge, that seeks to shape conduct by working through our desires, aspirations, interests and beliefs, for definite but shifting end with a diverse or relatively unpredictable consequences and outcomes (Dean 1999, p.11).

Above Dean's work claims that those being governed will experienced human conduct as" something that can be regulated, controlled, shaped and turned to specific ends", by implementing various techniques based on various information (Dean, 1999, p. 11). Thus, the government has the power to accomplish its vision and mission accordingly. One of the important arguments was pointed under the governmentality is coercive power. The coercive in this context referring to the UNDRIP which highlighted the importance of Orang Asli wellbeing and culture. Yet in Malaysia context, whatever been started by UNDRIP been altered according to the Malaysian Federal Constitution where the enactment related to the indigenous people is fall under the Act 134. Thus, the conduct of govermentality specially on the state and recognition of Orang Asli remained under the control of Government on their level of treatment. The coercive power generated by both legislative which UNDRIP and Federal Constitutional on the treatment of Orang Asli in Malaysia influenced by the conduct of govermentality on how managing this community in Malaysia.

Extending Foucault's work, Chinnasamy (2013) in her research on analysing Malaysia's political landscape through the lense of governmentality has claims that coercive power is a power that present in the form of sovereign, that enforce the law, which is centralised, repressive and originated in the rule of the Constitution or King. Chinnasamy (2013, p. 71) explains that Foucault makes a distinction between social relations of communication and political apparatuses. In analysing power relations, he distinguishes sovereignty and pastoral power as two 'games'. On the other hand, pastoral power connects to the individuals' needs and ideas, which are exercised through what Foucault referred to as 'technologies of the body' (Chinnasamy, 2013, p. 66). 'Our societies proved to be really demonic since they happened to combine these two games: the citizen game and the shepherd-flock game: in what we call the modern state' (Foucault, 1988 cited in Chinnasamy 2013, p.66). Thus, the struggle of Orang Asli community in Malaysia is continuous where the pastoral power produced by this community through their networking of JAKOA and Tok Batin or Community Leaders continuous seeing as overlooked and as a struggle mode between the government and Orang Asli community. The pastoral power taken by the indigenous individuals towards demanding their rights was seen as contentious site or struggle site between the pastoral power and sovereign power.

For instance, in Malaysia's case, Chinnasamy (2013) argues that coercive power pull the forces of democracy and authoritarian practices at the same time. Obviously, the Federal Constitution of Malaysia is the supreme law of Malaysia since 1957 as stated in the article of 4 (1). It outlines the basic reference guidelines upon which the functions of all components relating to power operate. The Constitution acknowledged the Federation as a Constitutional Monarchy with the King, Yang di-Pertuan Agong, as the Head of State under the Article 32(1) and established the three main branches of government: the legislative branch consisting of the House of Representatives (Dewan Rakyat) and Senate (Dewan Negara); the executive branch led by the PM and his Cabinet Ministers; and the judicial branch headed by the Federal 
Court (Part IV Chapter 4 - Federal Legislature, Part IV Chapter 3 - The Executive and Part IX for the judicial branch) (Federal Constitution, 2014). Example of constitution in Malaysia.

Similar argument can be interpreted on the development of indigenous people in the Malaysia, aligned with the country's Federal Constitution and United Nation's UNDRIP's objectives in fulfilling the indigenous people's right. Thus, the government is in the multifaceted situation where there is assimilations aims that raised from the national political economy role, which partly coordinated through the federal constitution and at the same time try to altered its demand according to the UNDRIP. Thus, it can be concluded that even though both countries agreed with the formation of UNDRIP at the United Nation's level, but in terms of implementation wise, there are few limitations been countered by these countries due to the existing democracy practices in the country and state's role in national political economy role and nation building.

Thus, there is question whether UNDRIP's aims towards the development of the Orang Asli can be viewed as symbolism or substantive. Local scholar Faruqi (2009) claims that the international laws has recognize the minimum standard on the protection of the human rights. Yet, it is important to ensure how far the standard can play significant role in protecting certain groups of communities in the country especially countries that has Indigenous group. So, the protection of human rights especially UNDRIP's role in protecting the indigenous people involved issues in certain countries in undertaking the most suitable measures in enforcing the standards domestically. Thus, the measurement or evaluation of govermentality conducts towards the community of Orang Asli is a long struggle. It is obvious that demands of this community been addressed occasionally based on the emerging issues which suddenly gained attention of Malaysians at glance such as water issue, COVID-19 safety aspects and also news on Orang Asli villages been locked up due to the spread of COVID-19 within the community. Hence, the management and level of indigenous treatment should ongoing and not been treated as occasionally. Thus, the governmentality and conducts of Orang Asli has to be improved.

Is Malaysia have such enforcing laws that can be fulfilled the rights of the indigenous people? Is UNDRIP is a mere symbolic or substantive? According to Gale $(2005$, p. 66$)$ substantive is the 'recognition of Indigenous rights' in terms of culture, language, Aboriginality and identity. Whereas, symbolic is 'an emphasis on tolerance and being a united nation' (Gale, 2005, p. 64). Therefore, substantive is an element which is deeper not only in recognizing the rights to the Indigenous people but also need to be accepted by all of the people in the nation.

Since UNDRIP takes place in a social-political environment in Malaysia for Orang Asli, UNDRIP outlined several guidelines such as self-determination, rights and equity which should be given to the Indigenous people. In other words UNDRIP should be not just as 'tolerance' but it could be more towards 'recognitions of rights'. By doing so, it can recognize 'the first people' in our land. Although several efforts has been taken to standardize with guidelines outlined by the UNDRIP, both of the countries are not yet to achieve the substantive level as implemented by UNDRIP. In Malaysia's context, according to Rohaida (2010, p. 18) Malaysian rights especially for Orang Asli are depends on the 'internal factors' and not as 'designated' or 'implemented' internationally. This refers that, the international laws concerning the Orang Asli are the only protection for them in Malaysia. 
Governmentality work been used to examine the position of the Malaysian government in crisis communication relief management and preparedness including the formulation and development. Malaysian governments' rationality in formulating crisis communication relief management and preparedness policy can be considered under three reasons. Firstly, it was meant to help increase the quality of life and well-being of the population. Secondly, it was to provide a more efficient health style. Thirdly, it is aimed to transform the crisis communication relief management and preparedness in line with the global standard. The Government then saw mainstream lifestyle positively as an important channel for socioeconomic development and also compatible with the mainstream people. Even though the power is circulated through the state and its discourses, which is evidence from the various bills of indigenous policies and UNDRIP aims, there are transition processes occurred between the government and state. There are questions of assimilation, self- determination and how the Orang Asli rights been measured? Thus, power is not "the property of individuals", but at the same time, there is a secondary view that portrayed power is a "thing that controlled by individual(s) or group(s)". This is evident in Weber's (1978) idea in which power is conceptualised as "the chance of a man or a number of men to realize their own will even against the resistance of other who are participating in the action" (p.926). This justification can be resembled on the both countries' indigenous people positions. Whether from the both governments position and the Orang Asli who receiving it and at the same time against the state's assimilation aims. Thus, the implementation of power can be examined in terms of the relationship between two parties. In other words, power that an individual has, depends on the extent of the control an individual has over the behaviour of other people. It can be argued that the pastoral power utilised by the indigenous individuals through their networking agencies and power that's generated from the sovereignty which largely influenced by the coercive power which is Federal Constitutional need further examination on how this framework should be working for the benefits of indigenous people in the country.

At least to achieve the minimum requirement of what been stated by the UNDRIP. Thus, the question of wellbeing of Orang Asli community always been highlighted in media and government report. Therefore, the COVID-19 Communication Relief Management and Preparedness should be considered during this pandemic. Otherwise, it will be a long due struggle for the human conducts of govermentality towards the management of indigenous people in the country. The proposed model below illustrated communication crisis model among the indigenous community and the stakeholders. This can be considered as one of the samples of governmentality on managing the COVID-19 preparation and intervention during the COVID-19 crisis. Figure 1 is a model of communication crisis in terms of aid management and readiness for pre and post-transmission of infectious diseases for indigenous peoples. The proposal for the development of this model is for this research study and is in the early stages of formation based on the researchers' observations of the current COVID-19 situation. However, the outcome of the final module will be clear from the findings of all stakeholders involved in this process which will have an impact on the distribution and flow of work / roles / responsibilities among stakeholders. important. It is hoped that the Crisis Communication Relief Management (Preparedness) Crisis Communication Model will become an SOP for the indigenous community to prepare for the future spread of infectious diseases. 


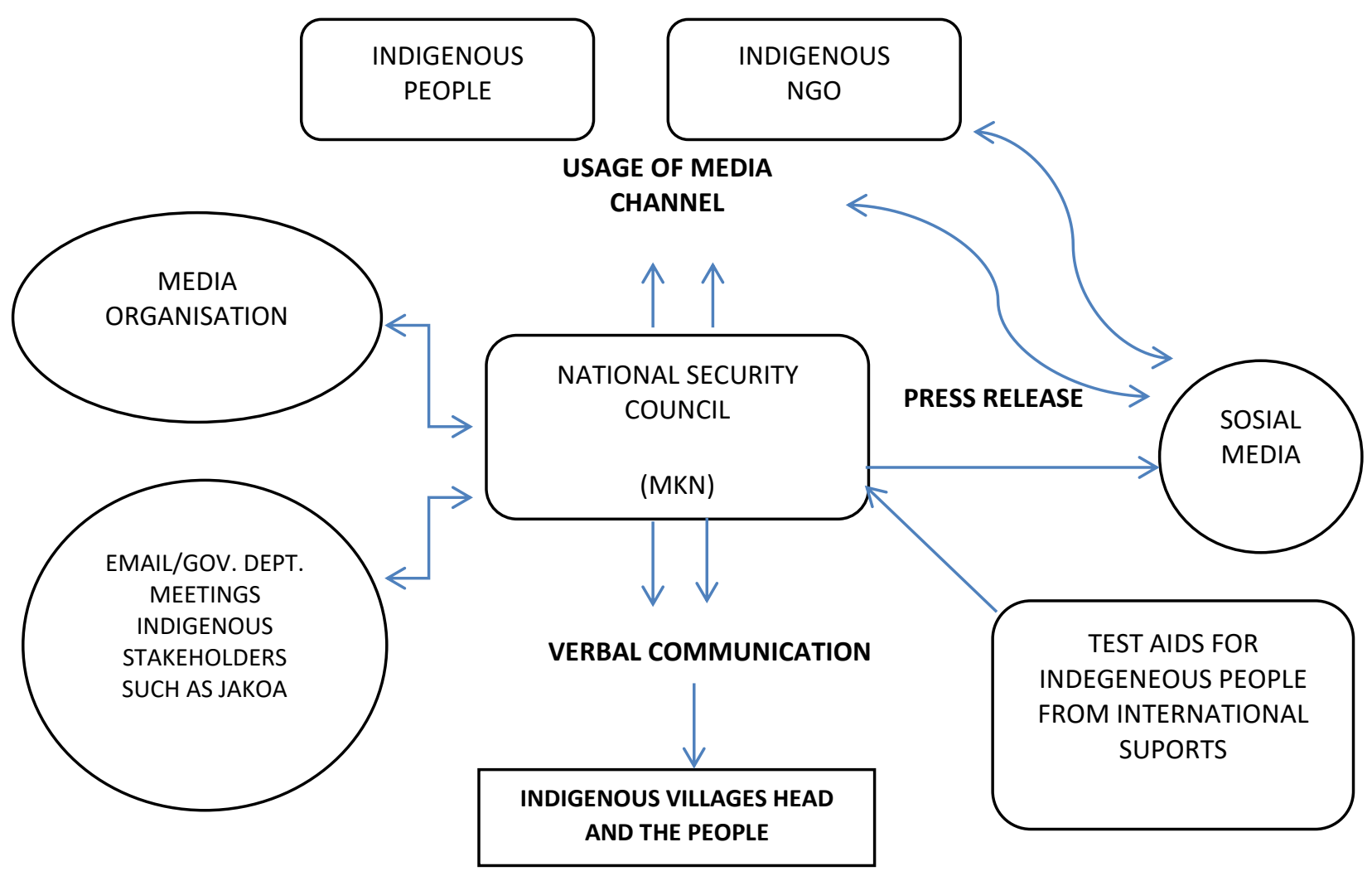

Figure 1: Communication Management Relief \& State of Preparedness on the Spread of COVID 19 Infectious Disease for the Indigenous People

As the impact of the positive cases and the increasing death following the COVID-19 infectious disease increase, it will reflect the importance of management of infectious diseases in Malaysia. Therefore, the setting of a specific policy as a plan of intervention into the policy of risk management of infectious diseases is important, especially for marginalized groups such as the indigenous community in Malaysia. Risk management around the world is constantly changing and moving towards a comprehensive approach in response to scientific approaches, research findings on post-traumatic emotional stress are also limited so it is important to analyze and identify them in order to minimize the emotional pain experienced by People Natural in ensuring their endurance and survival.

Indeed, the need to integrate treatment and treatment interventions requires an urgent demand for national initiatives to help the vulnerable to recover following this crisis in the Malaysian context. Given the increasing number of positive COVID-19 cases happening around the world, and in particular in Malaysia, it is important that post-traumatic intervention is given more attention than it has been in the past. Therefore, new interventions are crucial and must be implemented to ensure that victims of both COVID-19 and family members face the possibility of long-term negative emotional trauma.

The COVID-19 disaster will leave us a lot impacts that need to be learned and improved. Therefore, initial preparations and simulations of the preparations taken must be tested repeatedly to ensure their effectiveness. The need to establish a central body that regulates indigenous peoples during pandemics and outbreaks is very important. Distribution and 
communication need to be transparent, fast and effective for the flow of communication to flow smoothly and efficiently.

The coordination of coordination between agencies and teamwork between us is very much needed especially during this outbreak. We need to put aside political, religious and personal differences. We need to focus and focus on humanitarian aid. The announcement of the Public Service Announcement (PSA) for home steps can be a good example of raising awareness among the public. Malaysia is now taking the example of PSAs to raise awareness and provide information on safety steps during the spread of infectious diseases and allows people to make preparations.

\section{Conclusion}

As such, COVID-19, cannot be separated from the issues of indigenous peoples. It is just like any other issue facing the Native community such as issues of rights, equity, climate, deforestation, threats to food security and marginalization and racial discrimination. Therefore, prevention of global infectious diseases needs to be addressed in this indigenous community. As such, the initiatives provided to support the health and welfare of the Indigenous people during the COVID-19 pandemic need to be holistic, culturally safe and communist. The need for a centralized body to enable the indigenous people to refer to the status and information of the outbreak of the disease. It was very important during the current outbreak of the COVID-19 outbreak. The level of command and communication must be transparent for effective communication flow as well as effective communication in crisis management to avoid confusion among indigenous peoples. Integration, cohesion and teamwork are all needed especially in the event of an infectious disease outbreak. Put aside political, religious and personal beliefs but must focus on supporting humanitarian factors. Transparency in disseminating information should be done effectively. The functions and responsibilities of each governing body should be clear and focused on target groups such as Indigenous Peoples. This is to avoid conflicts of interest during the crisis as each one involves certain costs such as budget, time and life.

\section{References}

Chinnasamy, S. (2013). A Study of The Impact of The Internet, Malaysiakini.com and Democratising Forces on The Malaysian General Election 2008. (PhD), University of Adelaide, Australia.

Dean, M. M. (1999). Governmentality: Power and Rule in Modern Society. London: SAGE.

Department of Health Australia. (2020). Coronavirus (COVID-19) advice for Aboriginal and Torres Strait Islander peoples and remote communities. . Australia: Department of Health, Australian Government.

Faruqi, S. S. (2009). Human Rights, International Law and Municipal Courts. Paper presented at the Conference SUHAKAM, Kuala Lumpur, Kuala Lumpur.

Foucault, M. (1988). Politics and reason. In L. Krizman (Ed.), Michael: Politics, Philosophy, Cultural (pp. 57-85). London: Routledge.

Foucault, M. (1991). Governmentality. In M. Foucault, G. Burchell, C. Gordon, \& P. Miller (Eds.), The Foucault effect: studies in governmentality: with two lectures by and an interview with Michel Foucault. Chicago: University of Chicago Press.

Gale, P. (2005). The politics of fear: lighting the Wik. Australia: Pearson Education Australia. 
Gordon, C. (1991). Government rationality: An introduction. In M. Foucault, G. Burchell, C. Gordon, \& P. Miller (Eds.), The Foucault effect : studies in governmentality : with two lectures by and an interview with Michel Foucault. Chicago: University of Chicago Pres. Jabatan Kemajuan Orang Asli. (2016). Data Maklumat Asas Orang Asli 2016. Kuala Lumpur: Jabatan Kemajuan Orang Asli Malaysia.

Mills, S. (2003). Michel Foucault. London: Routledge.

Ministry of Health Malaysia. (2019). Kematian Orang Asli Kuala Koh. Putrajaya: Ministry of Health Malaysia.

National Aboriginal Community Controlled Health Organisation. (2020). COVID-19 Resources for Aboriginal and Torres Strait Islander communities. Canberra, Australia: National Aboriginal Community Controlled Health Organisation.

National Indigenous Australia Agency. (2020). Corona Virus (COVID-19). Australia: National Indigenous Australia Agency.

Nicholas, C. (2002). Organizing Orang Asli identity. In G. Benjamin \& C. Chou (Eds.), Tribal Communities in The Malay World: Historical, Cultural and Social Perspectives (pp. 119136). Singapore: Institute of Southeast Asian Studies.

Nicholas, C. (2005). Integration and modernization of the Orang Asli: the impact on culture and identity. Paper presented at the Paper presented at the 1st International Conference on the Indigenous People, Kuala Lumpur.

Razali, M. F., Rosnon, M. R., \& Sarjit, S. G. (2021). Kesejahteraan Subjektif Kewangan dalam kalangan Orang Asli Mah Meri di Pulau Carey, Selangor. Malaysian Journal of Social Sciences and Humanities (MJSSH), 6(7), 27-39

Rohaida, N. (2010). Malaysian Perspective on Human Rights. Journal of Law, 14, 17-33.

Rosnon, M. R. (2016). Indigenous education policies in Malaysia and Australia: a study of the recognition of indigenous rights and self-determination. (PhD), University of South Australia, Adelaide South Australia.

Rosnon, M. R. (2020). Impak virus kepada masyarakat peribumi global. Berita Harian. Retrieved from https://www.bharian.com.my/rencana/muka10/2020/04/672739/impak-viruskepada-masyarakat-peribumi-global

Rosnon, M. R., \& Abu Talib, M. (2019). Indigenous Education Rights: The Malaysian Case. International Journal of Academic Research in Business and Social Sciences, 9(10), 149167.

Rosnon, M. R., Abu Talib, M., \& Abdul Rahman, W. N. A. F. (2019). Self-Determination of Indigenous Education Policies in Australia: The Case of the Aboriginal People and Torres Strait Islander People. Pertanika Journal of Social Sciences \& Humanities, 27(S1), 267-284.

Rosnon, M. R., \& Sara, C. (2015). Discourse Of Indigenous Education Policy: The Malaysian Case. International Journal for Innovation Education and Research, 3(10), 126-140.

Rosnon, M. R., Sarjit, S. G., Shamsul Azahari, Z. B., N. Alia Fahada, W. A. R., \& Adam Danial, H. G. (2019). Petunjuk pembangunan komuniti orang Asli: Suatu analisis penggunaan barangan dan perkhidmatan. GEOGRAFIA Malaysian Journal of Society and Space, 15(1), 132-146.

Sarjit, S. G., Rosnon, M. R., \& Redzuan, M. (2010). Acculturation of Consumerism Among The Orang Asli Community in Jelebu, Negeri Sembilan. Petanika Journal Social Sciences and Humanities, 18(2), 321-331.

Smart, B. (2002). Michel Foucault. New York: Routledge. 
Smith-Morris, C., \& DeLuca, D. (2020). CoronaVirus, Indigenous Peoples and Global Advocacy. Cultural Survival. Retrieved from https://www.culturalsurvival.org/news/coronavirusindigenous-peoples-and-global-advocacy

The Star. (2021). Covid-19: 784 Orang Asli test positive, eight deaths reported, says Perak police chief. Retrieved from

https://www.thestar.com.my/news/nation/2021/08/12/covid-19-784-orang-aslitest-positive-eight-deaths-reported-says-perak-police-chief

UNDRIP. (2007). United Nations Declaration of The Rights of Indigenous People. Retrieved from United Nation:

World Health Organization. (2021a). Coronavirus disease (COVID-19): Situation Report - 140. Retrieved 23 January 2021, from World Health Organization https://www.who.int/docs/default-source/coronaviruse/situationreports/20200608-covid-19-sitrep-140.pdf?sfvrsn=2f310900_2

World Health Organization. (2020b). WHO Director-General's opening remarks at the media briefing on COVID-19 [Press release]. Retrieved from https://www.who.int/dg/speeches/detail/who-director-general-s-opening-remarksat-the-media-briefing-on-covid-19---11-march-2020

Worldometers. (2021). COVID-19 Coronavirus Pandemic [Press release]. Retrieved from https://www.worldometers.info/coronavirus/ 